\title{
PENGGUNAAN MODEL PEMBELAJARAN KOOPERATIF TIPE STUDENT TEAMS ACHIEVEMENT DIVISION (STAD) UNTUK MENINGKATKAN PEMAHAMAN KONSEP MATERI OPERASI HITUNG PERKALIAN PADA SISWA KELAS IV
}

\author{
Acep Roni Hamdani ${ }^{1}$ \\ Rohayati $^{2}$ \\ ${ }^{1}$ Mahasaiswa Pascasarjana UPI \\ ${ }^{2}$ SDN Nugraha Pelita \\ 1acepronihamdani@rocketmail.com \\ 2rohayati9569@gmail.com
}

\begin{abstract}
This research is based on the low understanding of the concept of Mathematics students in learning Mathematics material of multiplication operation in SD Negeri Nugraha Pelita. The problem is caused by the learning process that is still using conventional methods. This makes learning tends to be boring and students find it difficult to understand the learning materials that have been delivered, so that the impact of student understanding is likely to be low. Student Teams Achievement Division (STAD) cooperative learning model is very effective to be used as solution to solve the learning problem that happened during this time. The method used in this research is PTK method (Classroom Action Research). The subject of this research is the fourth grade students of SD Negeri Nugraha Pelita in the academic year 2017/2018 with the number of 33 people. Based on the results of learning and research analysis it can be concluded that the model of cooperative learning type Student Teams Achievement Division (STAD) can improve students' learning comprehension on Mathematics subjects of multiply counting operations in the fourth grade of SD Negeri Nugraha Pelita.
\end{abstract}

Keywords: Cooperative Learning Model Type Student Teams Achievement Division (STAD), Understanding Concepts, Operation Counting Multiplication

\begin{abstract}
ABSTRAK
Penelitian ini dilatarbelakangi rendahnya pemahaman konsep Matematika siswa pada pembelajaran Matematika materi operasi hitung perkalian di SD Negeri Nugraha Pelita. Permasalahan tersebut disebabkan proses pembelajaran yang masih menggunakan metode konvensional. Hal ini menjadikan pembelajaran cenderung membosankan dan siswa merasa kesulitan dalam memahami materi pembelajaran yang telah disampaikan, sehingga dampaknya pemahaman siswa cenderung rendah. Model pembelajaran kooperatif tipe Student Teams Achievement Division (STAD) sangat efektif dijadikan solusi untuk mengatasi permasalahan pembelajaran yang terjadi selama ini. Metode yang digunakan pada penelitian ini adalah metode PTK (Penelitian Tindakan Kelas). Subjek penelitian ini adalah siswa kelas IV SD Negeri Nugraha Pelita pada tahun pelajaran 2017/2018 dengan
\end{abstract}


jumlah 33 orang. Berdasarkan hasil pembelajaran dan analisis penelitian maka dapat disimpulkan bahwa model pembelajaran kooperatif tipe Student Teams Achievement Division (STAD) dapat meningkatkan pemahaman belajar siswa pada mata pelajaran Matematika tentang operasi hitung perkalian di kelas IV SD Negeri Nugraha Pelita.

Kata kunci : Model Pembelajaran Kooperatif Tipe Student Teams Achievement Division (STAD), Pemahaman Konsep, Operasi Hitung Perkalian 


\section{A. Pendahuluan}

Pendidikan ditujukan untuk mencerdaskan kehidupan bangsa dan meningkatkan kualitas sumber daya manusia Indonesia. Melalui upaya peningkatan kualitas pendidikan pada semua jenjang yang memungkinkan semua warganya memperoleh pendidikan yang layak untuk mengembangkan setiap potensi yang dimiliki oleh warga Indonesia. Pendidikan memberikan dampak bagi kemajuan bangsa dan negara. Suatu bangsa dikatakan maju dapat dilihat dari pendidikan bangsa itu sendiri.

Dalam proses pembelajaran siswa tidak hanya mengenal atau mempelajari satu mata pelajaran saja, ada beberapa mata pelajaran yang mesti dikuasai dan dipelajari oleh siswa demi menambah pengetahuan dan ilmu-ilmu lainnya yang berguna bagi diri sendiri dan orang-orang disekitarnya. Salah satunya mata pelajaran yang dipelajari siswa di sekolah yaitu mata pelajaran matematika. Pembelajaran matematika menjadi hal yang wajib dipelajari oleh siswa di Sekolah Dasar, karena konsep matematika berpengaruh pada kehidupan siswa.

Menurut Piaget (dalam John W.Santrock : 308) dapat disimpulkan bahwa "Pemikiran anak-anak usia Sekolah Dasar pada usia 7-11 tahun disebut pemikiran operasional konkret (concrete operational thought). Menurut Piaget, operasi adalah hubungan-hubungan logis di antara konsep-konsep. Sedangkan operasi konkret adalah aktivitas mental yang difokuskan pada objek-objek. Pada tahap ini anak mulai berpikir logis dan sistematis untuk mencapai pemecahan masalah.

Masalah yang dihadapi dalam tahap ini bersifat konkret. Anak akan merasa kesulitan bila menghadapi masalah yang bersifat abstrak". Mata pelajaran matematika merupakan bidang studi yang diajarkan pada semua jenjang pendidikan mulai dari Sekolah Dasar kelas rendah hingga perguruan tinggi. Hal ini menunjukkan betapa pentingnya peran matematika dalam kehidupan. 
Matematika adalah salah satu disiplin ilmu yang diperlukan dalam kehidupan sehari-hari. Namun dalam kenyataan seringkali siswa mengalami kesulitan dalam menggunakan ide-ide dasar, konsep-konsep matematika dalam kehidupan sehari-hari. Hal ini disebabkan karena pembelajaran matematika selama ini hanya menekankan pada hasil tidak menekankan pada prosesnya. Pemahaman konsep matematika siswa Sekolah Dasar sangat penting, karena dengan penguasaan konsep akan memudahkan siswa dalam mempelajari matematika. Pada setiap pembelajaran diusahakan lebih ditekankan pada penguasaan konsep agar siswa memiliki bekal dasar yang baik untuk mencapai kemampuan dasar yang lain seperti penalaran, komunikasi, koneksi dan pemecahan masalah.

Menurut Depdiknas (2001: 9) disebutkan bahwa secara khusus, tujuan mata pelajaran matematika pada jenjang pendidikan di Sekolah Dasar adalah sebagai berikut :

1. Memahami konsep matematika, menjelaskan keterkaitan antar konsep dan mengaplikasikan konsep atau algoritma, secara luwes, akurat, efisien, dan tepat dalam pemecahan masalah.

2. Menggunakan penalaran pada pola dan sifat, melakukan manipulasi matematika dalam membuat generalisasi, menyusun bukti, atau menjelaskan gagasan dan pernyataan matematika.

3. Memecahkan masalah yang meliputi kemampuan memahami masalah, merancang model matematika, menyelesaikan model dan menafsirkan solusi yang diperoleh.

4. Mengomunikasikan gagasan dengan symbol, tabel, diagram, atau media lain untuk memperjelas keadaan atau masalah.

5. Memiliki sikap menghargai kegunaan matematika dalam kehidupan, yaitu memiliki rasa ingin tahu, perhatian, dan minat dalam mempelajari matematika, serta sikap ulet dan percaya diri dalam pemecahan masalah.

Berdasarkan alasan di atas, Departemen Pendidikan Nasional sebagai instansi yang berwenang 
mengatur sistem pendidikan menyusun secara rinci tujuan pembelajaran matematika dalam Kurikulum Tingkat Satuan Pendidikan 2006. Namun sampai saat ini, masih banyak kendala yang dihadapi dalam upaya merealisasikan tujuan pembelajaran tersebut. Salah satu yang menjadi kendala adalah bentuk pembelajaran matematika yang digunakan oleh guru lebih banyak menggunakan metode pengajaran konvensional yang menyebabkan siswa merasa jenuh saat proses belajar mengajar. Selain itu, kurangnya pemahaman siswa terhadap konsep matematika yang dipelajari saat proses pembelajaran. Hal ini tentu akan berpengaruh terhadap prestasi belajar yang dicapai siswa. Siswa yang kurang paham terhadap materi ajar yang dipelajari dengan baik akan berdampak kepada hasil tes siswa dengan menunjukan hasil belajar yang lebih rendah.

Matematika sering kali hanya dipahami sebagai rumus-rumus yang sulit sehingga banyak siswa yang kurang menyukainya. Bagi siswa pelajaran matematika dianggap pelajaran yang paling sulit, menakutkan, dan sangat tidak menyenangkan, sehingga hasil prestasi matematika sangat kurang, belum tercapainya tujuan dan kompetensi, belum sesuai dengan harapan guru, orang tua maupun siswa sendiri. Salah satu pokok bahasan yang dianggap sulit dalam matematika adalah Operasi Hitung Perkalian. Pembelajaran yang dilakukan oleh guru secara konvensional saat pembelajaran menjadi dampak terhadap kurangnya pemahaman siswa terhadap konsep pembelajaran matematika. Maka dari itu diperlukan pemahaman atau proses yang cukup lama dalam menanamkan konsep tersebut. Hal tersebut dapat dilakukan dengan menerapkan suatu pendekatan model pengajaran yang menarik bagi siswa serta bermakna bagi siswa sehingga dapat diserap oleh siswa dengan mudah.

Seorang guru harus menciptakan suasana belajar secara efektif dan efisien. Guru harus meningkatkan kesempatan belajar bagi siswa (kuantitas) dan meningkatkan mutu (kualitas) 
mengajarnya. Ini berarti guru harus memiliki kompetensi dalam pengelolaan pembelajaran, penguasaan materi pembelajaran, penguasaan metode pembelajaran, memilih dan menentukan media dan alat pembelajaran, serta pembuatan instrumen evaluasi, sehingga guru yang memiliki kompetensi tersebut diharapkan akan mampu menciptakan suasana belajar yang efektif dan lebih optimal untuk semua siswa.

Guru juga memiliki kewajiban untuk memperbaiki strategi pembelajarannya. Jika ia mengetahui bahwa kondisi prestasi belajar siswanya masih rendah maka harus mengupayakan bagaimana supaya kompetensi siswa dapat meningkat. Upaya tersebut diantaranya adalah memilih model pembelajaran yang mampu membawa proses pembelajaran yang menyenangkan dan meningkatnya pemahaman dan hasil belajar siswa pada pembelajaran konsep matematika Sekolah Dasar.

Pada dasarnya, Kurikulum Tingkat Satuan Pembelajaran (KTSP) menuntut adanya partisipasi aktif dari seluruh siswa. Jadi, kegiatan belajar berpusat pada siswa, guru sebagai motivator dan fasilitator di dalamnya agar suasana kelas lebih hidup. Dengan melihat kurangnya keaktifan dan belum optimalnya prestasi belajar siswa, maka perlu dicari jalan keluar untuk memecahkan persoalan tersebut. Hal yang harus dilakukan adalah menggunakan model pembelajaran yang cocok dengan kondisi siswa. Model pembelajaran tersebut diterapkan supaya siswa dapat berfikir kritis, logis dan dapat memecahkan masalah dengan sikap terbuka, kreatif dan inovatif.

Pembelajaran kooperatif terutama tipe Student Teams Achievement Division (STAD) dianggap cocok diterapkan dalam pendidikan di Indonesia karena sesuai dengan budaya bangsa Indonesia yang menjunjung tinggi nilai gotong royong. Maka dari itu, perlu dikenalkan model pembelajaran kooperatif tipe Student Teams Achievement Division (STAD). Model tersebut dapat membuat siswa berpartisipasi pada saat proses 
pembelajaran berlangsung. Di sini siswa dapat mengembangkan keterampilannya berhitung Perkalian dengan adanya kerjasama. Model pembelajaran kooperatif tipe Student Teams Achievement Division (STAD) merupakan salah satu dari model pembelajaran aktif.

Menurut Slavin (dalam Rusman $2012: 213)$ model STAD (Student Teams Achievement Division) merupakan variasi pembelajaran kooperatif yang paling banyak diteliti. Model ini juga sangat mudah diadaptasi, telah digunakan dalam matematika, IPA, IPS, bahasa inggris, teknik dan banyak subjek lainnya, dan pada tingkat Sekolah Dasar sampai perguruan tinggi. Lebih jauh slavin memaparkan bahwa : "Gagasan STAD adalah memacu siswa agar saling mendorong dan membantu satu sama lain untuk menguasai keterampilan yang diajarkan guru". Model pembelajaran kooperatif tipe Student Teams Achievement Division (STAD) juga suatu model pembelajaran yang secara langsung maupun tidak langsung menuntut peran aktif dari tiap siswa untuk berpartisipasi dalam kegiatan belajar mengajar yang sedang berlangsung.

Berdasarkan observasi awal di kelas IV SD Negeri Nugraha Pelita Kecamatan Jalancagak, Kabupaten Subang, setelah dilakukan pengamatan melalui proses pembelajaran pada mata pelajaran matematika, menunjukan bahwa salah satu faktornya yaitu masih rendahnya pemahaman konsep matematika siswa kelas IV SD Negeri Nugraha Pelita. Kurangnya pemahaman siswa terhadap konsep matematika yang diajarkan karena siswa hanya menghafal tanpa memahami maksud dan isinya. Proses pembelajaran yang masih konvensional, kurang memperhatikan pemanfaatan media pembelajaran dan kurangnya penggunaan pendekatan dalam proses pembelajaran. Terdapat juga pada nilai hasil belajar siswa kelas IV SD Negeri Nugraha Pelita pada materi ajar Operasi Hitung Perkalian sekitar $73 \%$ mendapatkan nilai di bawah KKM (Kriteria Ketuntasan Minimal) dan sisanya sudah 
mencapai nilai di atas KKM Kriteria Ketuntasan Minimal).

\section{B. Landasan Teori}

1. Model

Pembelajaran

Kooperatif Tipe Student

Teams

Achievement

Division(STAD)

a. Pengertian Tipe STAD

Menurut Slavin (2005:11-13)

Student Team Achievement Division (STAD). Dalam STAD, para siswa di bagi dalam tim belajar yang terdiri atas empat orang yang berbeda beda tingkat kemampuan, jenis kelamin, dan latar belakang etniknya. Guru menyampaikan pelajaran, lalu siswa bekerja dalam tim mereka untuk memastikan bahwa semua anggota tim telah menguasai pelajaran. Selanjutnya, semua siswa mengerjakan kuis mengenai materi secara sendirisendiri di mana saat itu mereka tidak diperbolehkan untuk saling bantu.

Skor kuis para siswa dibandingkan dengan rata-rata pencapaian mereka sebelumnya, dan kepada masing-masing tim akan diberikan poin berdasarkan tingkat kemajuan yang diraih siswa dibandingkan hasil yang mereka capai sebelumnya. Poin ini kemudian dijumlahkan untuk memperoleh skor tim, dan tim yang berhasil memenuhi kriteria tertentu akan mendapatkan sertifikat atau penghargaan lainnya. Seluruh rangkaian kegiatan, termasuk presentasi yang disampaikan guru, praktik tim, dan kuis biasanya memerlukan waktu 3-5 periode kelas.

STAD telah digunakan dalam berbagai mata pelajaran yang ada, mulai dari, matematika, bahasa, seni, sampai dengan ilmu sosial dan ilmu pengetahuan ilmiah lain, dan telah digunakan mulai dari siswa kelas dua sampai perguruan tinggi. Gagasan utama dari STAD adalah untuk memotivasi siswa supaya dapat saling mendukung dan membantu satu sama lain dalam menguasai kemampuan yang diajarkan oleh guru. Jika para siswa ingin agar timnya mendapat penghargaaan tim. Mereka harus membantu teman satu timnya untuk mempelajari materinya. Mereka harus mendukung teman satu timnya untuk bisa melakukan yang terbaik, menunjukan norma bahwa 
belajar itu penting, berharga, dan menyenangkan.

Para siswa bekerja sama setelah guru menyampaikan materi pelajaran. Mereka boleh bekerja berpasangan dan membandingkan jawaban masing-masing, mendiskusikan setiap ketidaksesuaian, dan saling membantu satu sama lain jika ada yang salah dalam memahami. Mereka boleh mendiskusikannya dari pendekatan penyelesaian masalah, atau mereka juga boleh saling memberikan kuis mengenai objek yang sedang mereka pelajari. Mereka bekerja dengan teman satu timnya, menilai kekuatan dan kelemahan mereka untuk membantu mereka berhasil dalam kuis.

Meski para siswa belajar bersama, mereka tidak boleh saling bantu dalam mengerjakan kuis. Tiap siswa harus tahu materinya. Tanggung jawab individual seperti ini memotivasi siswa untuk memberi penjelasan dengan baik satu sama lain, karena satusatunya cara bagi tim untuk berhasil adalah dengan membuat semua anggota tim menguasai informasi atau kemampuan yang diajarkan karena skor tim didasarkan pada kemajuan yang dibuat anggotanya dibandingkan hasil yagn dicapai sebelumnya ( kesempatan sukses yang sama).

Semua siswa punya kesempatan untuk menjadi "bintang" tim dalam minggu tersebut, baik dengan memperoleh skor yang lebih tinggi dari rekor mereka sebelumnya maupun dengan membuat jawaban kuis yang sempurna, yang selalu akan memberikan skor maksimum tanpa menghiraukan rata-rata skor terakhir siswa. STAD lebih merupakan metode umum dalam mengatur kelas ketimbang metode komprehensif dalam mengajarkan mata pelajaran tertentu, guru menggunakan pelajaran mereka sendiri dan materi-materi lain.

\section{b. Langkah-Langkah}

\section{Pembelajaran STAD}
1) Penyampaian Tujuan dan Motivasi

$$
\text { Menyampaikan }
$$

tujuan pelajaran yang ingin dicapai pada pembelajaran tersebut dan memotivasi siswa untuk belajar.

2) Pembagian Kelompok 
Siswa dibagi ke dalam beberapa kelompok, dimana setiap kelompoknya terdiri dari 4-5 siswa yang

memprioritaskan heterogenitas (keragaman) kelas dalam prestasi akademik, gender/jenis kelamin, rasa atau etnik.

3) Presentasi Guru

Guru menyampaikan materi pelajaran dengan terlebih dahulu menjelaskan tujuan pelajaran yang ingin dicapai pada pertemuan tersebut serta pentingnya pokok bahasan tersebut dipelajari. Guru memberi motivasi siswa agar dapat belajar dengan aktif dan kreatif. $\mathrm{Di}$ dalam proses pembelajaran guru di bantu oleh media, demonstrasi, pernyataan atau masalah nyata yang terjadi dalam kehidupan sehari-hari. Dijelaskan juga tentang keterampilan dan kemampuan yang diharapkan dikuasai siswa, tugas dan pekerjaan yang harus dilakukan serta cara-cara mengerjakannya.

4) Kegiatan Belajar dalam Tim (Kerja Tim)

Siswa belajar dalam kelompok yang telah dibentuk. Guru menyiapkan lembaran kerja sebagai pedoman bagi kerja kelompok, sehingga semua anggota menguasai dan masingmasing memberikan konsribusi. Selama tim bekerja, guru melakukan pengamatan, memberikan bimbingan, dorongan dan bantuan bila diperlukan. Kerja tim ini merupakan ciri terpenting dari STAD.

5) Kuis (Evaluasi)

Guru mengevaluasi hasil belajar melalui pemberian kuis tentang materi yang dipelajari dan juga melakukan penilaian terhadap presentasi hasil kerja masingmasing kelompok. Siswa diberikan kursi secara individual dan tidak dibenarkan bekerja sama. Ini dilakukan untuk menjamin agar siswa secara individu bertanggung jawab kepada diri sendiri dalam memahami bahan ajar tersebut. Guru menetapkan skor batas penguasaan untuk setiap soal, misalnya $60,75,84$, dan seterusnya sesuai dengan tingkat kesulitan siswa.

6) Penghargaan Prestasi Kuis Setelah pelaksanaan kuis, guru memeriksa hasil kerja siswa dan diberikan angka dengan 
rentang 0-100. Pemberian hadiah dan pengakuan skor kelompok. Setelah masing-masing kelompok atau tim memperoleh predikat, guru memberikan hadiah atau penghargaan kepada masingmasing kelompok sesuai dengan prestasinya (kriteria tertentu yang ditetapkan guru).

\section{c. Lima Komponen STAD}

Menurut Slavin (2005: 143). "STAD terdiri dari lima komponen utama yaitu presentasi kelas, tim, kuis, skor kemajuan individual, dan rekognisi tim". Yaitu sebagai berikut 1) Presentasi kelas

Materi dalam STAD pertamatama diperkenalkan dalam presentasi di dalam kelas. Ini merupakan pengajaran langsung seperti yang sering kali di lakukan atau diskusi pelajaran yang di pimpin oleh guru, tetapi bisa juga memasukan presentasi audiovisual. Bedanya presentasi kelas dengan pengajaran bisa hanyalah bahwa presentasi tersebut haruslah benar-benar berfokus pada unit STAD. Dengan cara ini, para siswa akan menyadari bahwa mereka harus benar-benar memberi perhatian penuh selama presentasi kelas, karena dengan demikian akan sangat membantu mereka mengerjakan kuis-kuis, dan skor kuis mereka menentukan skor tim mereka.

2) $\mathrm{Tim}$

Tim terdiri dari empat atau lima siswa yang mewakili seluruh bagian dari kelas dalam hal kinerja akademik, jenis kelamin, ras dan etnisitas. Fungsi utama dari tim ini adalah memastikan bahwa semua anggota tim benar-benar belajar, dan lebih khususnya lagi adalah untuk mempersiapkan anggotanya untuk bisa mengerjakan kuis dengan baik.

3) Kuis

Setelah satu atau dua periode setelah guru memberikan presentasi dan sekitar satu atau dua periode praktik tim, para siswa akan mengerjakan kuis individual. Para siswa tidak di perbolehkan untuk saling membantu dalam mengerjakan kuis.

4) Skor Kemajuan Individual

Gagasan di balik skor kemajuan individual adalah untuk memberikan kepada tiap siswa tujuan kinerja yang akan dapat dicapai apabila mereka bekerja 
lebih giat dan memberikan kinerja yang lebih baik dari pada sebelumnya. Tiap siswa dapat memberikan kontribusi poin yang maksimal kepada timnya dalam sistem skor ini, tetapi tidak ada siswa yang dapat melakukannya tanpa memberikan usaha mereka yang terbaik. Tiap siswa diberikan " awal ", yang diperoleh dari rata-rata kinerja siswa selanjutnya akan mengumpulkan poin untuk tim mereka berdasarkan tingkat kenaikan skor kuis mereka dibandingkan dengan skor awal mereka.

5) Rekognisi Tim

Tim akan mendapatkan sertifikat atau bentuk penghargaan yang lain apabila skor rata-rata mereka mencapai kriteria tertentu. Skor tim siswa dapat juga digunakan untuk menentukan dua puluh persen dari peringkat mereka.

\section{Metode Penelitian}

Motode penelitian yang digunakan dalam penelitian ini adalah PTK (Penelitian Tindakan Kelas). Penelitian tindakan kelas adalah penelitian yang terstruktur.
Pada penelitian ini menggunakan model Kemmis dan Mc. Taggart dimana dalam model penelitian ini ada beberapa siklus (dalam Suharsimi Arikunto, 2006:93). Kemudian di dalam siklus tersebut masih terdapat beberapa komponen yang harus diperhatikan, yaitu perencanaan (planning), tindakan (action), observasi (observation), dan refleksi .

Penelitian tindakan kelas ini dilaksanakan di SDN Nugraha Pelita Jl. Lapang Olahraga Kecamatan Jalancagak Kabupaten Subang tahun ajaran 2017/2018 pada semester pertama. Penelitian ini dilakukan pada seluruh siswa kelas IV SD Negeri Nugraha Pelita yang berjumlah 33 orang siswa, dengan jumlah 15 orang siswa lakilaki dan 18 orang siswa perempuan.

\section{Pembahasan}

1. Peningkatan Pemahaman Konsep Materi Operasi Hitung Perkalian dengan Penerapan Model Pembelajaran Kooperatif Tipe Student Teams Achievement Division 
(STAD) di kelas IV SD Negeri Nugraha Pelita.

\section{a. Siklus I}

Siklus I merupakan pemberlakuan tindakan awal penelitian dengan menggunakan model pembelajaran Kooperatif Tipe Student Teams Achievement Division (STAD). Penelitian siklus I ini dilaksanakan sebanyak dua kali pertemuan, yaitu tanggal 04, dan 06 September 2017. Dalam tindakan siklus I dilakukan melalui empat tahapan yang secara berurutan yaitu merencanakan, melakukan tindakan, melakukan observasi dan refleksi.

\section{1) Tahap Perencanaan}

Hal-hal yang dilakukan pada tahap perencanaan siklus I adalah sebagai berikut:

a) Membuat

Rencana

Pelaksanaan Pembelajaran (RPP) materi operasi hitung perkalian dengan menggunakan model pembelajaran Kooperatif Tipe Student Teams Achievement Division (STAD).

b) Menyiapkan media yang digunakan dalam proses pembelajaran yaitu papan bilangan dan LKS.

c) Menyusun dan menyiapkan lembar observasi. Lembar observasi ini ada 2 macam, yaitu lembar aktivitas guru dan aktivitas siswa.

d) Menyiapkan soal evaluasi untuk mengetahui kemampuan siswa setelah mempelajari materi.

e) Peneliti menyiapkan kamera untuk mendokumentasikan proses pembelajaran berlangsung dari awal sampai akhir pembelajaran.

\section{2) Tahap Tindakan}

Pelaksanaan tindakan pada siklus I ini adalah melaksanakan yang telah dipersiapkan atau dirancang pada tahap perencanaan. Siklus ke I dilaksanakan pada hari senin tanggal 04 dan hari rabu tanggal 06 September 2017 pembelajaran materi operasi hitung perkalian berlangsung pada jam pelajaran pertama dengan alokasi waktu $2 \mathrm{x}$ 35 menit.

a) Pertemuan Pertama

(1) Kegiatan Awal 
Pada tahap ini guru mengkondisikan siswa untuk berdo'a dan siap untuk belajar, selanjutnya guru mengecek kehadiran siswa. Guru melakukan apresepsi yaitu dengan senam otak secara bersama-sama, setelah itu guru menjelaskan materi dan tujuan pembelajaran yang akan dilaksanakan. Memotivasi siswa dan menyampaikan prosedur pembelajaran yang akan digunakan yaitu model pembelajaran Student Teams Achievement Division (STAD).

\section{(2) Kegiatan Inti}

Pada inti pembelajaran, guru menyampaikan apersepsi dengan bertanya pada siswa, "anak-anak, pernahkah kalian mempelajari atau mengetahui tentang operasi hitung perkalian?" dan siswa menjawab pernah bu saat di kelas 3". Ada juga yang menjawab belum pernah. Selanjutnya, siswa diberi penjelasan tentang materi operasi hitung perkalian dengan menggunakan media yang telah disiapkan. Melalui pendapat siswa kemudian guru mengajak siswa menyimpulkan apa itu operasi hitung perkalian. Setelah itu, guru juga memberikan kesempatan kepada siswa untuk bertanya tentang hal-hal yang belum dipahami.

Setelah itu guru membagi siswa ke dalam kelompok secara heterogen, siswa dibagi menjadi 56 kelompok, guru membagikan LKS kepada setiap kelompok untuk dikerjakan secara berdiskusi dan setiap anggota kelompok harus mampu memahami soal LKS yang di diskusikan untuk mendapatkan kemajuan nilai pada setiap anggota kelompok dan guru membimbing siswa di dalam kelompok agar setiap kelompok berdiskusi dengan seluruh anggotanya untuk kemajuan skor evaluasi dan mendapat pengharhaan kelompok yang diinginkan. Setelah itu guru meminta perwakilan kelompok tersebut untuk mempresentasikan jawaban hasil diskusi di depan kelas secara bergantian antar kelompok.

\section{(3) Kegiatan Penutup}

Pada tahap setiap siswa di dalam kelompok mengerjakan soal evaluasi secara individu dan tidak bekerja sama dengan anggota kelompok lainnya sebagai acuan 
dalam menilai pemahaman siswa pada materi yang telah dipelajari. setelah itu guru bersama siswa bertanya jawab meluruskan kesalah pahaman dan memberikan kesimpulan. Setelah itu guru menutup pelajaran dengan berdo'a bersama.

\section{b) Pertemuan Kedua}

\section{(1) Kegiatan Awal}

Pada tahap ini guru mengkondisikan siswa untuk berdo'a dan siap untuk belajar, selanjutnya guru mengecek kehadiran siswa. Guru melakukan apresepsi yaitu dengan senam otak secara bersama-sama, setelah itu guru menjelaskan materi dan tujuan pembelajaran yang akan dilaksanakan. Memotivasi siswa dan menyampaikan prosedur pembelajaran yang akan digunakan yaitu model pembelajaran Student Teams Achievement Division (STAD).

\section{(2) Kegiatan Inti}

Pada inti pembelajaran, guru menyampaikan apersepsi dengan bertanya pada siswa tentang materi operasi hitung perkalian yang telah dipelajari di pertemuan ke 1 . Selanjutnya, siswa diberi penjelasan tentang materi operasi hitung perkalian dengan menggunakan media yang telah disiapkan.

Melalui pendapat siswa kemudian guru mengajak siswa menyimpulkan apa itu operasi hitung perkalian. Setelah itu, guru juga memberikan kesempatan kepada siswa untuk bertanya tentang hal-hal yang belum dipahami. Guru membagi siswa ke dalam kelompok secara heterogen, siswa dibagi menjadi 5-6 kelompok, guru membagikan LKS kepada setiap kelompok untuk dikerjakan secara berdiskusi dan setiap anggota kelompok harus mampu memahami soal LKS yang di diskusikan untuk mendapatkan kemajuan nilai pada setiap anggota kelompok dan guru membimbing siswa di dalam kelompok agar setiap kelompok berdiskusi dengan seluruh anggotanya untuk kemajuan skor evaluasi dan mendapat penghargaan kelompok yang diinginkan.

Setelah itu guru meminta perwakilan kelompok tersebut untuk mempresentasikan jawaban 
hasil diskusi di depan kelas secara bergantian antar kelompok.

\section{(3) Kegiatan Penutup}

Pada tahap setiap siswa di dalam kelompok mengerjakan soal evaluasi secara individu dan tidak bekerja sama dengan anggota kelompok lainnya sebagai acuan dalam menilai pemahaman siswa pada materi yang telah dipelajari. Setelah siswa mengerjakan soal evaluasi, guru melakukan perhitungan skor kelompok dan skor individu untuk dapat mengetahui kelompok yang mendapat penghargaan kelompok lalu diberitahukan kepada siswa kelompok yang mendapat penghargaan.

Setelah itu guru bersama siswa bertanya jawab meluruskan kesalah pahaman dan memberikan kesimpulan. Setelah itu guru menutup pelajaran dengan berdo'a bersama.

\section{3) Tahap Pengamatan Observasi}

Dalam pembelajaran di Siklus I ini diharap dapat berpengaruh besar terhadap pemahaman konsep matematis siswa, yang ditunjukkan dengan nilai belajar siswa. Penilaian ini diberikan pada akhir pertemuan yaitu Lembar Kerja Siswa untuk penilaian kelompok dan Lembar Evaluasi untuk penilaian individu. Penilaian mengacu pada standar ketuntasan belajar mengajar yang ditetapkan disekolah.

\section{4) Tahap Refleksi}

Berdasarkan hasil observasi dan hasil diskusi dengan observer setelah pelaksanaan siklus I secara umum peneliti telah melaksanakan pembelajaran dengan baik. Siswa sangat antusias dan aktivitas siswa pun meningkat dengan menggunakan model pembelajaran Student Teams Achievement Division (STAD). kemampuan siswa pun dalam memahami materi pembelajaran cukup meningkat, namun masih ada kegiatankegiatan yang harus di perbaiki untuk lebih meningkatnya pemahaman siswa terhadap materi tersebut pada siklus II, diantaranya sebagai berikut :

(1) Tidak tersampaikannya kompetensi yang harus dicapai oleh siswa. 
(2) Pada saat pembentukan kelompok siswa cenderung tidak kondusif.

(3) Pada saat pembentukan kelompok membutukan waktu yang lama.

(4) Siswa kurang biasa mengikuti kegiatan diskusi kelompok, masih ada siswa yang asik dengan kesibukannya masingmasing.

\section{Kekurangan-kekurangan}

yang telah diuraikan di atas hendaknya diperbaiki untuk memperoleh hasil yang lebih baik pada pelaksanaan siklus II, baik dari RPP, mengontrol kegiatan siswa saat berdiskusi, dan membimbing siswa saat berdiskusi.

\section{b. Siklus II}

Siklus II merupakan pelaksanaan tindakan yang dilakukan pada putaran kedua dalam penelitian dengan menggunakan model pembelajaran Kooperatif Tipe Student Teams Achievement Division (STAD) setelah dilakukannya siklus I yang belum memberikan hasil yang maksimal. Penelitian siklus II ini dilaksanakan sebanyak dua kali pertemuan, yaitu tanggal 13, dan
15 September 2017. Dalam tindakan siklus II dilakukan melalui empat tahapan yang secara berurutan yaitu merencanakan, melakukan tindakan, melakukan observasi dan refleksi.

\section{1) Tahap Perencanaan}

Hal-hal yang dilakukan pada tahap perencanaan siklus II adalah sebagai berikut:

(1) Membuat

Rencana

Pelaksanaan Pembelajaran (RPP) materi operasi hitung perkalian dengan menggunakan model pembelajaran Kooperatif Tipe Student Teams Achievement Division (STAD).

(2) Menyiapkan media yang digunakan dalam proses pembelajaran yaitu papan bilangan dan LKS.

(3) Menyusun dan menyiapkan lembar observasi. Lembar observasi ini ada 2 macam, yaitu lembar aktivitas guru dan aktivitas siswa.

(4) Menyiapkan soal evaluasi untuk mengetahui kemampuan siswa setelah mempelajari materi. 
(5) Peneliti menyiapkan kamera untuk mendokumentasikan proses pembelajaran berlangsung dari awal sampai akhir pembelajaran.

\section{2) Tahap Tindakan}

Pelaksanaan tindakan pada siklus II ini adalah melaksanakan yang telah dipersiapkan atau dirancang pada tahap perencanaan. Siklus ke II dilaksanakan pada hari rabu tanggal 13 dan hari jum'at tanggal 15 September 2017 pembelajaran materi operasi hitung perkalian berlangsung pada jam pelajaran pertama dengan alokasi waktu $2 \mathrm{x}$ 35 menit.

\section{a) Pertemuan Pertama}

\section{(1) Kegiatan Awal}

Pada tahap ini guru mengkondisikan siswa untuk berdo'a dan siap untuk belajar, selanjutnya guru mengecek kehadiran siswa. Guru melakukan apresepsi yaitu dengan menyanyikan lagu perkalian secara bersama-sama, setelah itu guru menjelaskan materi dan tujuan pembelajaran yang akan dilaksanakan. Memotivasi siswa dan menyampaikan prosedur

\begin{tabular}{llr} 
pembelajaran & \multicolumn{1}{c}{ yang } & akan \\
digunakan & yaitu & model \\
pembelajaran & Student & Teams
\end{tabular}
Achievement Division (STAD).

\section{(2) Kegiatan Inti}

Pada inti pembelajaran, guru menyampaikan apersepsi dengan bertanya pada siswa, "anak-anak, setelah kita mempelajari operasi hitung perkalian, apa sajakah manfaat yang akan kita dapatkan?" dan siswa menjawab banyak bu, jadi tahu cara mengalikan sesuatu barang di rumah, dan ada yang menjawab jadi mengetahui cara mengalikan suatu bilangan". Selanjutnya, siswa diberi penjelasan tentang materi operasi hitung perkalian dengan menggunakan media yang telah disiapkan.

Melalui pendapat siswa kemudian guru mengajak siswa menyimpulkan apa itu operasi hitung perkalian. Setelah itu, guru juga memberikan kesempatan kepada siswa untuk bertanya tentang hal-hal yang belum dipahami. Guru membagi siswa ke dalam kelompok secara heterogen, siswa dibagi menjadi 5-6 kelompok, guru membagikan LKS kepada 
setiap kelompok untuk dikerjakan secara berdiskusi dan setiap anggota kelompok harus mampu memahami soal LKS yang di diskusikan untuk mendapatkan kemajuan nilai pada setiap anggota kelompok dan guru membimbing siswa di dalam kelompok agar setiap kelompok berdiskusi dengan seluruh anggotanya untuk kemajuan skor evaluasi dan mendapat penghargaan kelompok yang diinginkan. Setelah itu guru meminta perwakilan kelompok tersebut untuk mempresentasikan jawaban hasil diskusi di depan kelas secara bergantian antar kelompok.

\section{(3) Kegiatan Penutup}

Pada tahap setiap siswa di dalam kelompok mengerjakan soal evaluasi secara individu dan tidak bekerja sama dengan anggota kelompok lainnya sebagai acuan dalam menilai pemahaman siswa pada materi yang telah dipelajari. Setelah siswa mengerjakan soal evaluasi, guru melakukan perhitungan skor kelompok dan skor individu untuk dapat mengetahui kelompok yang mendapat penghargaan kelompok lalu diberitahukan kepada siswa kelompok yang mendapat penghargaan. Setelah itu guru bersama siswa bertanya jawab meluruskan kesalah pahaman dan memberikan kesimpulan. Setelah itu guru menutup pelajaran dengan berdo'a bersama.

\section{b) Pertemuan Kedua}

\section{(1) Kegiatan Awal}

Pada tahap ini guru mengkondisikan siswa untuk berdo'a dan siap untuk belajar, selanjutnya guru mengecek kehadiran siswa. Guru melakukan apresepsi yaitu dengan bermain tebak hasil perkalian suatu bilangan, setelah itu guru menjelaskan materi dan tujuan pembelajaran yang akan dilaksanakan. Memotivasi siswa dan menyampaikan prosedur pembelajaran yang akan digunakan yaitu model pembelajaran Student Teams Achievement Division (STAD).

\section{(2) Kegiatan Inti}

Pada inti pembelajaran, guru menyampaikan apersepsi dengan bertanya pada siswa, "anak-anak, setelah kita mempelajari operasi hitung perkalian, apa sajakah 
manfaat yang akan kita dapatkan?" dan siswa menjawab banyak bu, jadi tahu cara mengalikan sesuatu barang di rumah, dan ada yang menjawab jadi mengetahui cara mengalikan suatu bilangan". Selanjutnya, siswa diberi penjelasan tentang materi operasi hitung perkalian dengan menggunakan media yang telah disiapkan.

Melalui pendapat siswa kemudian guru mengajak siswa menyimpulkan apa itu operasi hitung perkalian. Setelah itu, guru juga memberikan kesempatan kepada siswa untuk bertanya tentang hal-hal yang belum dipahami. Setelah itu guru membagi siswa ke dalam kelompok secara heterogen, siswa dibagi menjadi 5-6 kelompok, guru membagikan LKS kepada setiap kelompok untuk dikerjakan secara berdiskusi dan setiap anggota kelompok harus mampu memahami soal LKS yang di diskusikan untuk mendapatkan kemajuan nilai pada setiap anggota kelompok dan guru membimbing siswa di dalam kelompok agar setiap kelompok berdiskusi dengan seluruh anggotanya untuk kemajuan skor evaluasi dan mendapat penghargaan kelompok yang diinginkan. Setelah itu guru meminta perwakilan kelompok tersebut untuk mempresentasikan jawaban hasil diskusi di depan kelas secara bergantian antar kelompok.

\section{(3) Kegiatan Penutup}

Pada tahap setiap siswa di dalam kelompok mengerjakan soal evaluasi secara individu dan tidak bekerja sama dengan anggota kelompok lainnya sebagai acuan dalam menilai pemahaman siswa pada materi yang telah dipelajari. Setelah siswa mengerjakan soal evaluasi, guru melakukan perhitungan skor kelompok dan skor individu untuk dapat mengetahui kelompok yang mendapat penghargaan kelompok lalu diberitahukan kepada siswa kelompok yang mendapat penghargaan. Setelah itu guru bersama siswa bertanya jawab meluruskan kesalah pahaman dan memberikan kesimpulan. Setelah itu guru menutup pelajaran dengan berdo'a bersama. 
5) Tahap Pengamatan / Observasi

Dalam pembelajaran di Siklus II ini diharap dapat berpengaruh besar terhadap pemahaman konsep matematis siswa, yang ditunjukkan dengan nilai belajar siswa. Penilaian ini diberikan pada akhir pertemuan yaitu Lembar Kerja Siswa untuk penilaian kelompok dan Lembar Evaluasi untuk penilaian individu. Penilaian mengacu pada standar ketuntasan belajar mengajar yang ditetapkan disekolah.

\section{6) Tahap Refleksi}

Berdasarkan hasil observasi dan hasil diskusi dengan observer setelah pelaksanaan siklus II secara umum peneliti telah melaksanakan pembelajaran dengan baik. Siswa sangat antusias dan aktivitas siswa pun meningkat dengan menggunakan model pembelajaran Student Teams Achievement Division (STAD). kemampuan siswa pun cukup meningkat, namun masih ada kegiatan-kegiatan yang harus di perbaiki untuk lebih meningkatnya pemahaman siswa terhadap materi tersebut pada siklus II, diantaranya sebagai berikut :

(1) Pada saat mengerjakan tugas kelompok siswa cenderung tidak kondusif.

(2) Masih ada siswa yang dari kelompok lain mengganggu kelompok lainnya saat berdiskusi.

(3) Siswa dalam mengikuti kegiatan diskusi kelompok, masih ada siswa yang asik dengan kesibukannya masingmasing.

Kekurangan-kekurangan

yang telah diuraikan di atas hendaknya diperbaiki untuk memperoleh hasil yang lebih baik pada pelaksanaan siklus III, baik dari RPP, mengontrol kegiatan siswa saat berdiskusi, dan membimbing siswa saat berdiskusi.

c. Siklus III

Siklus III merupakan pelaksanaan tindakan yang dilakukan pada putaran ketiga dalam penelitian dengan menggunakan model pembelajaran Kooperatif Tipe Student Teams Achievement Division (STAD) setelah dilakukannya siklus II yang belum memberikan hasil yang 
maksimal. Penelitian siklus III ini dilaksanakan sebanyak dua kali pertemuan, yaitu tanggal 20, dan 22 September 2017. Dalam tindakan siklus III dilakukan melalui empat tahapan yang secara berurutan yaitu merencanakan, melakukan tindakan, melakukan observasi dan refleksi.

\section{a. Tahap Perencanaan}

Hal-hal yang dilakukan pada tahap perencanaan siklus III adalah sebagai berikut:

1) Membuat Rencana Pelaksanaan Pembelajaran (RPP) materi operasi hitung perkalian dengan menggunakan model pembelajaran Kooperatif Tipe Student Teams Achievement Division (STAD).

2) Menyiapkan media yang digunakan dalam proses pembelajaran yaitu papan bilangan dan LKS.

3) Menyusun dan menyiapkan lembar observasi. Lembar observasi ini ada 2 macam, yaitu lembar aktivitas guru dan aktivitas siswa.

4) Menyiapkan soal evaluasi untuk mengetahui kemampuan siswa setelah mempelajari materi.
5) Peneliti menyiapkan kamera untuk mendokumentasikan proses pembelajaran berlangsung dari awal sampai akhir pembelajaran.

\section{b. Tahap Tindakan}

Pelaksanaan tindakan pada siklus II ini adalah melaksanakan yang telah dipersiapkan atau dirancang pada tahap perencanaan. Siklus ke II dilaksanakan pada hari rabu tanggal 13 dan hari jum'at tanggal 15 September 2017 pembelajaran materi operasi hitung perkalian berlangsung pada jam pelajaran pertama dengan alokasi waktu $2 \mathrm{x}$ 35 menit.

\section{1) Pertemuan Pertama \\ a) Kegiatan Awal}

Pada tahap ini guru mengkondisikan siswa untuk berdo'a dan siap untuk belajar, selanjutnya guru mengecek kehadiran siswa. Guru melakukan apresepsi yaitu dengan menyanyikan lagu perkalian secara bersama-sama, setelah itu guru menjelaskan materi dan tujuan pembelajaran yang akan dilaksanakan. Memotivasi siswa dan menyampaikan prosedur 


\begin{tabular}{lcr}
\hline pembelajaran & yang & akan \\
digunakan & yaitu & model \\
pembelajaran & Student & Teams \\
\multicolumn{2}{l}{ Achievement Division (STAD). }
\end{tabular}

\section{b) Kegiatan Inti}

Pada inti pembelajaran, guru menyampaikan apersepsi dengan bertanya pada siswa tentang materi operasi hitung perkalian yang sudah dipelajari di siklus I dan siklus II. Selanjutnya, siswa diberi penjelasan tentang materi operasi hitung perkalian dengan menggunakan media yang telah disiapkan.

Melalui pendapat siswa kemudian guru mengajak siswa menyimpulkan apa itu operasi hitung perkalian. Setelah itu, guru juga memberikan kesempatan kepada siswa untuk bertanya tentang hal-hal yang belum dipahami. Guru membagi siswa ke dalam kelompok secara heterogen, siswa dibagi menjadi 5-6 kelompok, guru membagikan LKS kepada setiap kelompok untuk dikerjakan secara berdiskusi dan setiap anggota kelompok harus mampu memahami soal LKS yang di diskusikan untuk mendapatkan kemajuan nilai pada setiap anggota kelompok dan guru membimbing siswa di dalam kelompok agar setiap kelompok berdiskusi dengan seluruh anggotanya untuk kemajuan skor evaluasi dan mendapat penghargaan kelompok yang diinginkan. Setelah itu guru meminta perwakilan kelompok tersebut untuk mempresentasikan jawaban hasil diskusi di depan kelas secara bergantian antar kelompok.

\section{c) Kegiatan Penutup}

Pada tahap setiap siswa di dalam kelompok mengerjakan soal evaluasi secara individu dan tidak bekerja sama dengan anggota kelompok lainnya sebagai acuan dalam menilai pemahaman siswa pada materi yang telah dipelajari. Setelah siswa mengerjakan soal evaluasi, guru melakukan perhitungan skor kelompok dan skor individu untuk dapat mengetahui kelompok yang mendapat penghargaan kelompok lalu diberitahukan kepada siswa kelompok yang mendapat penghargaan. Setelah itu guru bersama siswa bertanya jawab meluruskan kesalah pahaman dan memberikan kesimpulan. Setelah 
itu guru menutup pelajaran dengan berdo'a bersama.

\section{2) Pertemuan Kedua}

\section{a) Kegiatan Awal}

Pada tahap ini guru mengkondisikan siswa untuk berdo'a dan siap untuk belajar, selanjutnya guru mengecek kehadiran siswa. Guru melakukan apresepsi yaitu dengan bermain tebak hasil perkalian suatu bilangan, setelah itu guru menjelaskan materi dan tujuan pembelajaran yang akan dilaksanakan. Memotivasi siswa dan menyampaikan prosedur pembelajaran yang akan digunakan yaitu model pembelajaran Student Teams Achievement Division (STAD).

\section{b) Kegiatan Inti}

Pada inti pembelajaran, guru menyampaikan apersepsi dengan bertanya pada siswa tentang materi operasi hitung perkalian yang sudah dipelajari di siklus I dan siklus II. Selanjutnya, siswa diberi penjelasan tentang materi operasi hitung perkalian dengan menggunakan media yang telah disiapkan.
Melalui pendapat siswa kemudian guru mengajak siswa menyimpulkan apa itu operasi hitung perkalian. Setelah itu, guru juga memberikan kesempatan kepada siswa untuk bertanya tentang hal-hal yang belum dipahami. Guru membagi siswa ke dalam kelompok secara heterogen, siswa dibagi menjadi 5-6 kelompok, guru membagikan LKS kepada setiap kelompok untuk dikerjakan secara berdiskusi dan setiap anggota kelompok harus mampu memahami soal LKS yang di diskusikan untuk mendapatkan kemajuan nilai pada setiap anggota kelompok dan guru membimbing siswa di dalam kelompok agar setiap kelompok berdiskusi dengan seluruh anggotanya untuk kemajuan skor evaluasi dan mendapat penghargaan kelompok yang diinginkan. Setelah itu guru meminta perwakilan kelompok tersebut untuk mempresentasikan jawaban hasil diskusi di depan kelas secara bergantian antar kelompok.

c) Kegiatan Penutup

Pada tahap setiap siswa di dalam kelompok mengerjakan soal 
evaluasi secara individu dan tidak bekerja sama dengan anggota kelompok lainnya sebagai acuan dalam menilai pemahaman siswa pada materi yang telah dipelajari. Setelah siswa mengerjakan soal evaluasi, guru melakukan perhitungan skor kelompok dan skor individu untuk dapat mengetahui kelompok yang mendapat penghargaan kelompok lalu diberitahukan kepada siswa kelompok yang mendapat penghargaan. Setelah itu guru bersama siswa bertanya jawab meluruskan kesalah pahaman dan memberikan kesimpulan. Setelah itu guru menutup pelajaran dengan berdo'a bersama.

\section{c. Tahap Pengamatan Observasi}

Dalam pembelajaran di Siklus III ini diharap dapat berpengaruh besar terhadap pemahaman konsep matematis siswa, yang ditunjukkan dengan nilai belajar siswa. Penilaian ini diberikan pada akhir pertemuan yaitu Lembar Kerja Siswa untuk penilaian kelompok dan Lembar Evaluasi untuk penilaian individu. Penilaian mengacu pada standar ketuntasan belajar mengajar yang ditetapkan disekolah.

\section{d. Tahap Refleksi}

Berdasarkan hasil observasi dan hasil diskusi dengan observer setelah pelaksanaan siklus III secara umum peneliti telah melaksanakan pembelajaran dengan sangat baik. Siswa sangat antusias dan aktivitas siswa pun meningkat dengan menggunakan model pembelajaran Student Teams Achievement Division (STAD) pemahaman konsep matematis siswa pun menjadi meningkat.

\section{Aktivitas Siswa Terhadap} Mata Pelajaran Materi Operasi Hitung Perkalian dengan Penerapan Model Pembelajaran Kooperatif Tipe Student Teams Achievement Division (STAD) di kelas IV SD Negeri Nugraha Pelita.

Adapun untuk mengetahui peningkatan aktivitas siswa yang telah diteliti berdasarkan data tes observasi menunjukkan adanya peningkatan aktivitas siswa pada mata pelajaran matematika pada setiap siklus yang dijalani oleh siswa. Pada siklus I dapat di persentasikan sebesar 65\%. Kemudian pada siklus II mengalami 
peningkatan sebesar $75 \%$ dan terjadi peningkatan kembali pada siklus III menjadi 95\%. Dari hasil tes observasi berikut, menunjukan bahwa pada setiap siklus aktivitas mengalami peningkatkan dan itu memberikan arti bahwa siswa mengalami peningkatan dalam proses belajarnya dengan menggunakan model pembelajaran Student Teams Achievement Division (STAD) dalam proses pembelajaran yang diterapkan oleh guru sebagai peneliti.

\section{E. Kesimpulan}

Berdasarkan pembahasan hasil Penelitian Tindakan Kelas (PTK) yang dilaksanakan dalam tiga siklus mengenai pengaruh model pembelajaran Kooperatif Tipe Student Teams Achievement Division (STAD) pada pembelajaran matematika materi operasi hitung perkalian untuk meningkatkan pemahaman konsep matematis siswa di Kelas IV SD Negeri Nugraha Pelita Kabupaten Subang, maka peneliti dapat menarik kesimpulan sebagai berikut :
1. Perencanaan peningkatan pemahaman konsep materi operasi hitung perkalian dengan menggunakan model pembelajaran Kooperatif Tipe Student Teams Achievement Division (STAD) di kelas IV SD Negeri Nugraha Pelita adalah dengan membuat RPP (Rencana Pelaksanaan Pembelajaran) yang sistematis sama seperti pembuatan RPP pada umumnya, yaitu dengan menentukan standar kompetensi, kompetensi dasar, indikator, tujuan pembelajaran, materi pembelajaran, metode pembelajaran, sumber dan alat pembelajaran, dan langkahlangkah pembelajaran yang terdiri dari pendahuluan, kegiatan inti, penutup dan penilaian. Dalam perencanaan pembelajaran dengan menggunakan model pembelajaran Kooperatif Tipe Student Teams Achievement Division (STAD) mempunyai ciri khusus pada langkahlangkah pembelajarannya.

2. Model pembelajaran Kooperatif Tipe Student Teams 
Achievement Division (STAD)

di kelas IV SDN Nugraha Pelita dapat

meningkatkan

pemahaman konsep, hal ini dapat di lihat dari peningkatan persentase kelulusan dari nilai ketuntasan minimal (KKM), pada tindakan awal pretest persentase kelulusan sebesar $27 \%$ dari jumlah siswa 9 orang, pada siklus I sebesar $21,21 \%$ dari jumlah siswa 33 orang, pada siklus II sebesar $54,54 \%$ dari jumlah siswa 33 orang, dan pada siklus III persentase kelulusan siswa sebesar 93,93\% dari jumlah siswa 33 orang. Persentase kelulusan ini mencapai $93,93 \%$ pada saat test akhir atau posttest.

3. Aktivitas siswa pada pembelajaran matematika materi operasi hitung perkalian setelah menggunakan model pembelajaran Kooperatif Tipe Student Teams Achievement Division (STAD) di kelas IV SDN Nugraha Pelita mengalami peningkatan, hal ini dapat dilihat dari peningkatan persentase observasi pada siklus 1 persentase aktivitas siswa sebesar $65 \%$. Meningkat pada siklus 2 yaitu persentasenya $75 \%$ dan pada siklus 3 mengalami peningkatan yang cukup signifikan yaitu $95 \%$.

\section{DAFTAR PUSTAKA}

Arikunto, S. (2007). Manajemen Penelitian. Jakarta : Rineka Cipta.

Dadang (2017) Buku Kurikulum KTSP 2006 SD/MI Kelas IV Semester 1 dan 2 Lengkap.[Online].

Kiki, Asep Supriadi. (2015). Peningkatan Pemahaman Konsep Mengenai Dokumen Pribadi dan Keluarga Melalui Penerapan Model Pembelajaran Cooperative Learning Tipe STAD. Skripsi. Jurusan PGSD. STKIP Subang. Tidak diterbitkan.

Mei, Eko Hartati. (2011). Peningkatan Prestasi Belajar Siswa Kelas IV Operasi Penjumlahan dan Pengurangan Pecahan pada Soal Cerita Melalui Pendekatan Kooperatif Tipe Student Teams Achievement Division (STAD) SDN Kembangarum 03 Semarang. Skripsi. Universitas Negeri Semarang. Semarang : tidak diterbitkan.

Rusman. (2012). Model - Model Pembelajaran. Jakarta : PT Rajagrafindo Persada

E, Slavin Robert. (2005). Cooperative Learning Teori, 
Riset dan Praktik. Bandung :

Nusa Media

Sugiyono. (2015). Metode

penelitian pendidikan

pendekatan, kuantitatif

kualitatif, dan $R \& D$, . Bandung:

CV Alfabeta

Susanto, A. (2013). Teori Belajar

Pembelajaran Di Sekolah

Dasar. Jakarta

Prenadamedia Group

Vicky, Ririn Indryani. (2015).

Penerapan Pendekatan

Realistik Untuk Meningkatkan

Pemahaman Matematis

Siswa Di Sekolah Dasar.

Skripsi. Jurusan PGSD.

STKIP Subang. Tidak

diterbitkan.

W, Santrock J. ( 2002). Life Span

Development

perkembangan masa hidup,

Jakarta. Erlangga 